\title{
Long Infection Period for White Pine Blister Rust in Coastal British Columbia
}

R.S. H unt and G.D. J ensen

AdDITIONAL INDEX WORDS. currants, black currants, resistance

Summary. For the white pine blister rust disease (WPBR), reports conflict concerning the time of year the pathogen, Cronarti um ribicola J.C. Fisch., infects western white pine (Pinus monticola D. D on) and what needle age increments are most susceptible. To determine timing of infection, western white pine seedling were placed under infected currants ( $R$ i besnigrum L.) for 1 -week periods from $M$ ay to $N$ ovember. $N$ eedles became spotted and stems cankered after exposure to diseased currants from early summer until leaf drop in November. To determine what foliage age increment was most susceptible, 5-year-old seedlings were placed in a disease garden, and older trees were inoculated in stu. All age increments of pine foliage were susceptible to infection. For young seedlings, all age increments were about equally susceptible, but on some older seedlings and trees, the current year's foliage appeared more resistant than older foliage.

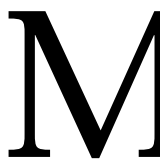

uch has been written about the seasonal timing of infection and the age increment of foliage infected by the introduced WPBR pathogen on eastern white pine (PinusstrobusL.), western white pine, and sugar pine (P. lambertiana D ougl.). $\mathrm{H}$ irt (1935) found teliospores germinated up to $22^{\circ} \mathrm{C}$ $\left(72{ }^{\circ} \mathrm{F}\right)$ and their basidiospores up to $21^{\circ} \mathrm{C}\left(70^{\circ} \mathrm{F}\right)$. Basidiospores exposed to sunlight or drying conditions survive a few hours (H irt, 1935; Spaulding and Rathbun-Gravatt, 1926). In Wisconsin, Van Arsdel et al. (1956) found diurnal summer temperature fluctuations of 15 to $25^{\circ} \mathrm{C}$ ( 59 to $77^{\circ} \mathrm{F}$ ) prevented formation of fertile teliospores, and that cooler, more stable, temperatures of September were necessary to permit viable inoculum development and infection of white pine. In eastern N orth America, York et al. (1927) and H irt (1942) obtained good infection of artificially inoculated seedlings in late, but not early August. Similarly, in I daho and $\mathrm{M}$ ontana, copious telia were formed under fall conditions and regularly used to produce inoculum for pines (Bingham, 1983). In British Columbia, copious telia were noted in late August to early September and cool moist conditions were favorable for infecting white pines in the fall (H unt, 1988; L achmund, 1933; Porter, 1960). Therefore, artificial inoculations for resistance screening typically occurred in September in Wisconsin, B ritish Columbia, I daho, and O regon. H owever, natural production of copious telia occurred in August in California (Kimmey and Wagener, 1961), J uly in India (Bagchee, 1950), and J une on R ibeslacustre (Pers.) Poir. in Pacific northwestern N orth America (M ielke, 1943).

Research scientist and biologist, respectively. $N$ atural Resources $C$ anada, C anadian Forest Service, Pacific Forestry Centre, 506 W. Burnside Rd., Victoria, BC V8Z 1M 5.

The cost of publishing this paper was defrayed in part by the payment of page charges. U nder postal regulations, this paper therefore must be hereby marked advertisement solely to indicate this fact. 
The weather in coastal British Columbia in June is often cool and moist, so it is possibly conducive to basidiosporeformation and whitepine infection. I f pine infection occurs early at the Pacific coast, it may permit the pathogen to become well established in host needles before the spots-only resistance (M CD onald and $H$ off, 1971) can function. This may explain why trees with this trait are resistant in the British Columbia interior ( $\mathrm{H}$ unt, 1994) but are susceptibleat the Pacific coast (H unt and M eagher, 1989).

Screening programs in British Columbia, Idaho, and O regon inoculate only the current foliage of 2-yearold seedlings. H owever, the age of theseinfection courtsmay not becomparable to those occurring in nature. Reports are conflicting concerning which age increment of foliage is the most important infection court. For eastern white pine, Patton (1961) reported the current year's needles were more susceptible than older needles, whereas H irt (1936) reported the reverse. Similarly for western white pine, Chapman (1934) and Snell (1936) found current year's needles susceptible while Pierson and Buchanan (1938) found current year's needles resistant. York et al. (1927) and Snell (1936) found current and 1-year-old needles to be about equally susceptible; Chapman (1934) found the 2year-old needles to be more susceptible; and H unt (1991) traced infection on inoculated seedlings only to current foliage.

The objectives of this study were to determine when WPBR infection occursin coastal B ritish Columbia and if current foliage of 2-year-old seedlings was a realistic inoculation target when screening seedling for resistance.

\section{Methods and materials}

To determine approximate timing for pine infection, $\mathrm{R}$ ibes were examined for telia when encountered in the field during the past 13 years. To determine when infection occurred, groups of potted western white pine seedlings were placed in a coastal disease garden (cultivated currants infected with C . ribi cola) under ambient conditionsat weekly intervals. I n 1991, groups of 12 seedlings were placed in the garden each week from 3 Aug. to 27 N ov. In 1997, groups of 10 seedlings were placed in the garden each week from 21 June to 5 Sept. They were then removed to locations where they could not become infected (safe locations). Control seedlings were maintained in the safelocations. I nfection spots were tallied the following spring and the seedlingswere observed for canker production for an additional 2 years.

To determine the susceptibility of needles of various ages, 87 5-year-old seedlings were placed in a disease garden in 1992 and infection spotstallied the following summer. They were observed for cankering over the next 2 years. I n natural settingson $V$ ancouver I sland (Renfrew, Cowichan and NorthWest Bay), 14 western white pines, aged 5 to 12 years, were inoculated by suspending telia-bearing $R$. bracteosum D oug. leaves on wire trays over their branches. N eedle spotting and branch cankering were observed as described above.

\section{Results}

Telial columns were observed on coastal R . bracteosum, R . lacustreand R . lobbi Gray, sparingly or in abundance from $M$ ay through to $N$ ovember in all years(1985-1998). N eedlespotting and subsequent cankering occurred in all groups of seedling exposed for weekly intervals in 1991. In the last week, few leaves were left on the currant plants. Rain occurred in only 6 of the 11 weeks in which infection occurred. H owever, the least spotting occurred in late September after a month without rain. In 1997, the greatest incidence of spotting and cankering occurred in groups from

T able 1. White pine blister rust needle spotting and cankering on western white pine seedlings placed for weekly intervals in a disease garden in 1997.

\begin{tabular}{lccc}
\hline $\begin{array}{l}\text { Placement } \\
\text { date }\end{array}$ & $\begin{array}{c}\text { Seedlings } \\
\text { infected } \\
(\%)\end{array}$ & $\begin{array}{c}\text { Mean } \\
\text { spots } \\
\text { (no.) }\end{array}$ & $\begin{array}{c}\text { Cankering } \\
(\%)^{\mathbf{y}}\end{array}$ \\
\hline June 21 & 100 & 88 & 80 \\
June 27 & 100 & 52 & 100 \\
July 4 & 100 & 52 & 100 \\
July 11 & 100 & 3 & 30 \\
July 18 & 100 & 6 & 40 \\
July 25 & 60 & 1 & 10 \\
Aug. 1 & 60 & 2 & 0 \\
Aug. 8 & 60 & 1 & 0 \\
Aug. 15 & 50 & 1 & 0 \\
Aug. 22 & 60 & 1 & 0 \\
Aug. 29 & 30 & 0 & 10 \\
Sept. 5 & 0 & 0 & 0 \\
Controls & 0 & 0 & 0 \\
\hline
\end{tabular}

z10 seedlings/ week.

yO bservations through M ay 1999.

the first 3 weeks (T able 1). Some of the early exposed seedlings produced cankers by the following $M$ arch and most produced pycnia in the spring and summer. Control seedlings in safe locations showed no signsor symptomsofWPBR.

Inoculation of the 87 5-year-old seedlingsresulted in cankersdeveloping on both 1-year-old (1991) and current (1992) growth incrementsin $72 \%$ of the seedlings, on only the current growth increment in $20 \%$ of the seedlings, and on only the 1-year-old growth increment in 8\%of theseedlings. Field inoculations of older trees produced variable results(Table2). Both the Renfrew and Cowichan locations were observed several times for needle infection spots. Spots were observed only at Cowichan, but not cankers, while at Renfrew and $\mathrm{N}$ orthWest Bay cankers were observed, but not needle spots.

\section{Discussion}

L achmund (1933) suggested that infection occurred in waveyears (about 1 year in 3); however, Kimmey and Wagener (1961) contended that infection occurred every year. In this study, telial columns were observed sparsely or in abundance on $\mathrm{R}$ ibesunder field conditions from as early as $\mathrm{M}$ ay to aslate as $\mathrm{N}$ ovember. The spotting and cankering data on the pines placed out for one-week intervalsindicate these telial columns lead to many infection episodes over a long time each year, starting in the spring. Condensation must be sufficient for basidiospore germination as infection oc-
Hortlechnology • July-September 2000 10(3) 
Table 2. Age of branch increments bearing white pine blister rust cankers from artificial inoculations in field situations on Vancouver I sland, B ritish Columbia.

\begin{tabular}{|c|c|c|c|c|c|c|}
\hline \multirow[b]{2}{*}{ Location } & \multirow{2}{*}{$\begin{array}{c}\text { In noculation } \\
\text { year }\end{array}$} & \multicolumn{2}{|c|}{ Tree } & \multicolumn{3}{|c|}{$\begin{array}{l}\text { C anker incidence } \\
\text { B ranch increment }\end{array}$} \\
\hline & & Age (yr) & No. & Current & 1-year & 2-year \\
\hline Renfrew & 1989 & 5 & 3 & $2(0)^{z}$ & $12(0)$ & $1(0)$ \\
\hline N orthWest Bay & 1991 & $5-11$ & 9 & $10(0)$ & $14(0)$ & $16(0)$ \\
\hline Cowichan & 1991 & 12 & 2 & $0(5)$ & $0(54)$ & $0(29)$ \\
\hline
\end{tabular}

zSpotting data in parentheses. M ean spot counts for 1-cm (0.39-inch) intervals on all inoculated branches; noninoculated branches lacked spots and cankers.

curred in the absence of rain. Wave infections may occur when the pathogen spreads to new areas (Mielke, 1943), but once the disease is established, multiple infection episodes per year would nullify wave years, at least in coastal British Columbia.

The spotting and cankering frequency demonstrate that some infection episodes in the early summer are more successful than fall infection episodes(Table1). This early coastal infection may explain why spots-only resistance fails on the coast ( $\mathrm{H}$ unt and $M$ eagher, 1989), but is effective in the British Columbiainterior (H unt, 1994).

The conflicting results reported in the literature (Chapman, 1934; $\mathrm{H}$ irt, 1936; Patton, 1961; Pierson and Buchanan, 1938; Snell, 1936; York et al., 1927), for the age increment of foliagemost susceptiblemay be partially explained by theage of the host. Patton (1961) inoculated seedlings and found current foliage to be highly susceptible, which parallelsobservationsfor screened seedlings (Bingham, 1983; H unt, 1988). In contrast, we observed the current foliage to be most resistant on a few inoculated 5-year-old trees and on older trees in the field at two locations; these observations parallel those for 6 to 8-year-old plantsby C hapman (1934); 4-year-old plantsby H irt (1936); and 5to 7-year-old plants by Pierson and Buchanan (1938). At one field location all foliage increments weresimilarly susceptible and this observation parallels that of York et al. (1927) and Snell (1936). The reason for thisvariability in susceptibility of foliage increments on older plants needs further study. The observation that cankers result from infection spots only from the current foliage (H unt, 1991) could not be repeated.

In screening for resistance to blister rust in western white pine, infection spot numbersare tallied and families with reduced needle lesion frequency (RNLF) are considered more resistant than familieswith high needle spotting frequencies ( $\mathrm{H}$ off and $M$ CD onald, 1980). H owever, for this trait to be important for much of the life of the tree, RN LF of current year's foliage on seedlings must correlate to RN LF of older foliage, particularly on older trees. The variability reported in the literature, and observed here on older plants, suggests that such correlations are unlikely, and may explain why H unt (1999) did not find any correlation between field resistanceand RNLF resistance. Perhaps RNLF is only a juvenile resistance mechanism. This, combined with the variability reported here, the apparent resistance of current foliage in some cases, and the lack of a correlation with field data (H unt, 1999) suggests that RNLF should be reevaluated as a selection trait for WPBR resistance.

\section{Literature cited}

Bagchee, K.D. 1950. Contributionsto our knowledge of the morphology, cytology and biology of Indian coniferous rust. Ind. For. Records (NS) Bot. 4(1):141.

Bingham, R.T. 1983. Blister rust resistant western white pine for the inland empire: The story of the first 25 years of the research and development program. U SD A For. Serv. Gen. Tech. Rpt. IN T-146.

Chapman, C.M . 1934. A study of the movement of the mycelium of $\mathrm{C}$ ronartium ribicola Fischer during the incubation period in Pinusmonticola Doug, p. 293298. In: Blister rust work in the far west. U SD A Div. Plant D is. Contrib.

H irt, R.R. 1935. O bservations on the production and germination of sporidia of Cronartium ribicola. Bul. N.Y. State Coll. For. Tech. Publ. 46.

H irt, R.R. 1936. The progress of blister rust in planted northern white pine. J. For. 34:506-511.

H irt, R.R. 1942. Therelation of certain meteorological factors to the infection of eastern white pine by the blister-rust fungus. Bul. N.Y. State Coll. For. Tech. Publ. 59.

H off, R.J. and G.I. M CD onald. 1980. I mproving rustresistant strains of inland western white pine. USDA For. Serv. Res. Paper IN T-245.

H unt, R.S. 1988. White pine improvement in British Columbia, p. 32-36. In: R.S. H unt (compiler). Proc. Western White Pine Symp., N akusp, B.C. Pacific For. Ctr., Victoria B.C.
H unt, R.S. 1991. The effect of age on the susceptibility to blister rust of western white pine seedlings. In H iratsuka, J.K. Samoil, P.V. Blenis, P.E. Crane, and B.L. Laishley (eds). Rusts of pine. Proc. 3rd Intl. U nion of For. Res. O rg. Rusts of pine working party Conf., Sept. 1989, Banff, AB. Can. For. Serv. Inf. R pt. N O R-X-317:287-290.

H unt, R.S. 1994. T ransferability of western white pine within and to British Columbia-blister rust resistance. Can. J. Plant Pathol. 16:273-278.

H unt, R.S. 1999. Blister rust cankering incidence in western white pine families selected for reduced spotting. Phytopathology 89:S35

H unt, R.S. and M.D. Meagher 1989. Incidence of blister rust on "resistant" white pine (Pinusmonticola and P. strobus) in coastal British Columbia plantations. Can. J. Plant Pathol. 11:419-423.

Kimmey, J.W. and W.W. Wagener. 1961. Spread of white pine blister rust from ribes to sugar pine in California and Oregon. U SD A For. Serv. Tech. Bul. 1251.

L achmund, H.G. 1933. M ethod of determining age of blister rust infection on western white pine. J. Agr. Res. 46:675-693.

M cD onald, G.I. and R.J. H off. 1971. Resistance to Cronartium ribicola in Pinusmonticola: Genetic control of needle-spots-only resistance factors. Can. J. For. Res. 1:197-202.

M ielke, J.L. 1943. White pine blister rust in western N orth America. Yale U niv. School of For. Bul. 52.

Patton, R.F. 1961. Theeffect of ageupon susceptibility of eastern white pine to infection by Cronartium ribicola. Phytopathology 51:429-434.

Pierson, R.K. and T.S. Buchanan. 1938. Susceptibility of needles of different ages on Pinus monticola seedlings to Cronartium ribicola infection. Phytopathology 28:833-839.

Porter, W.A. 1960. T esting for resistance to the blister rust disease of western white pine in British Columbia. Dept. Agr. For. Biol. Lab. Victoria, B.C.

Snell, W.H . 1936. The relation of the age of needles of Pinus strobus to infection by Cronartium ribicola. Phytopathology 26:1074-1080.

Spaulding, P. and A. Rathbun-Gravatt. 1926. The influence of physical factors on the viability of sporidia of Cronartium ribicola Fischer. J. Agr. Res. 33:397433.

York, H.H., W.H. Snell, and A. Rathbun-Gravatt. 1927. The results of inoculating Pinusstrobuswith the sporidia of Cronartium ribicola. J. Agr. Res. 34:497510.

Van Arsdel, E.P., A.J. Riker, and R.F. Patton. 1956. The effect of temperature and moisture on the spread of white pine blister rust. Phytopathology 46:307318.

Hortlechnology • July-September 2000 10(3) 